States. Analysis of 483 cases in man. N Engl f Med 1965;273:857-64, 915-22.

${ }^{3}$ Burke BJ, Searle JF, Mattingly D. Leptospirosis presenting with profuse haemoptysis. Br Med $\mathcal{F} 1972$;ii :982.

- Zlatzman M, Kallenbach JM, Goss GD, Lewis M, Zwi S, Gear JHS Adult respiratory distress syndrome in Leptospira canicola infection. Br Med F 1981;283:519-20.

5 Jacobs JH. Spondylitis following Weil's disease. Ann Rheum Dis 1951 10:61-4.

(Accepted 10 November 1983)

Department of Medicine, Whittington Hospital, London N19 5NF R J D WINTER, BSC, MRCP, medical registrar

A RICHARDSON, MB, BS, senior house officer

$M$ J LEHNER, MB, BS, house physician

B I HOFFBRAND, DM, FRCP, consultant physician

Correspondence to: Dr R J D Winter.

\section{Pyrexia of undetermined origin, diarrhoea, and primary cerebral lymphoma associated with acquired immunodeficiency}

We report on a heterosexual man who presented with chronic diarrhoea and fever associated with acquired immunodeficiency. Investigation, which included extensive serological studies, failed to show a cause for his fever.

\section{Case report}

A 47 year old Scotsman, who had returned to the United Kingdom after working in East Africa for many years, presented with profuse diarrhoea, weight loss, and consolidation in the right lung. Eighteen months previously he had presented to another hospital with fever, lymphadenopathy, and hepatosplenomegaly. He was also known to have had recurrent malaria. Initial tests showed haemoglobin concentration $7.8 \mathrm{~g} / \mathrm{dl}$, white cell count $4.5 \times 10^{9} / 1$, and platelet count $77 \times 10^{9} / 1$. The peripheral blood lymphocyte count was depressed (figure), recovered transiently, and then declined to a very low value. Erythrocyte sedimentation rate was $137 \mathrm{~mm}$ in the first hour. A Mantoux test yielded a negative result. $T$ cell marker studies were not performed. Serum IgG concentration was slightly increased at $1.67 \mathrm{~g} /$ $100 \mathrm{ml}$, and serum concentrations of IgA, IgM, IgE, and complement were all within normal limits.

For four months attempts to detect an infective cause for his fever were unsuccessful (figure). All viral titres except, transiently, titres to cytomegalovirus yielded negative results. There were no malarial parasites on the blood film. Serum alkaline phosphatase and $\gamma$-glutamyltransferase activities were raised (figure). The common and right hepatic ducts were dilated. Cholangitis could not be confirmed bacteriologically, and a cause for the dilated ducts was not established. Inflammatory bowel disease was excluded. In November he developed septicaemia due to Escherichia coli during a brief trial of treatment with prednisolone; in December his condition deteriorated considerably with the sudden onset of focal neurological signs. Computed tomography and a brain biopsy were undertaken. He died on 24 December.

At necropsy a poorly differentiated lymphocytic cerebral lymphoma centred on the left lentiform nucleus was found as well as toxoplasma cysts throughout both cerebral hemispheres. A lung abscess $4 \mathrm{~cm}$ long was present, from which Klebsiella pneumoniae and Candida albicans were isolated. The larger hepatic ducts were dilated and contained concretions of bile crystals. Cytomegalovirus inclusion bodies were found within epithelial cells of the bile ducts, periductal endothelial cells, the submucosa of the gall bladder and gut, and epithelial cells of the pancreas, thyroid, and lungs.

\section{Comment}

A previously healthy heterosexual man developed an illness characterised by prolonged fever, chronic diarrhoea, mucosal candidiasis, tuberculin anergy, lymphopenia, widespread multiple opportunistic infections, and primary lymphoma of the central nervous system. These features suggest a disorder of cell mediated immunity but give no insight into its cause. ${ }^{1}$ In retrospect it would have been interesting to have studied $\mathrm{T}$ lymphocyte subpopulations. Similar disturbances of immunity, however, have been seen in high risk groups-namely, in patients with viral, fungal, or mycobacterial infections or apparently after exposure to ultraviolet light-who do not develop opportunistic infections or unusual tumours. ${ }^{2}$ Our patient fulfilled the criteria for the acquired immunodeficiency syndrome. ${ }^{3}$ This term has become linked with "an outbreak of disease" undoubtedly related to immunodeficiency in the homosexual population of the United States of America, ${ }^{1}$ but similar abnormalities have been reported, not necessarily with manifestation of immunodeficiency, in drug abusers, Haitian immigrants, and patients with haemophilia, among others. ${ }^{1-4}$ In spite of this diversity a common aetiological agent has been suggested. ${ }^{2}$ Acquired immunodeficiency is not new; its manifestations are not unexpected, as evidenced by

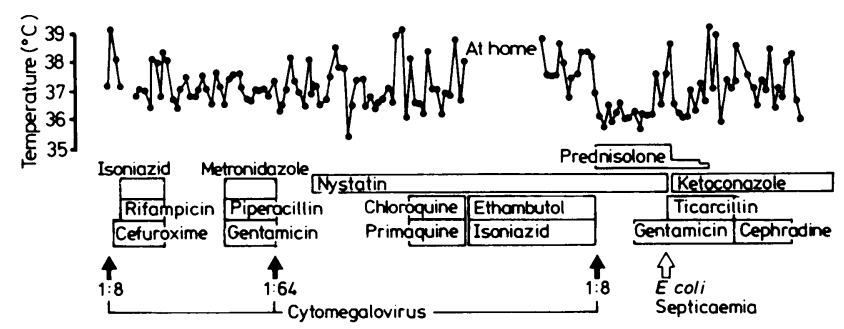

Jejunal aspirate showed Streptococcus faecalis and Enterabacter aerogenes Lundh meal : mean amylase activity $5 \mathrm{U} / \mathrm{ml}$, tryptic activity $0 \mathrm{U} / \mathrm{ml}$ Fluorescence antibaty negative for: Malaria Leishmaniasis Schistosomiasis Trypanosomiasis Amoebiasis

Serological tests
negafive tor:
Brucellosis
Toxoplasmosis
Syphilis
Legionnaires' disease
Q tever
Psittacosis
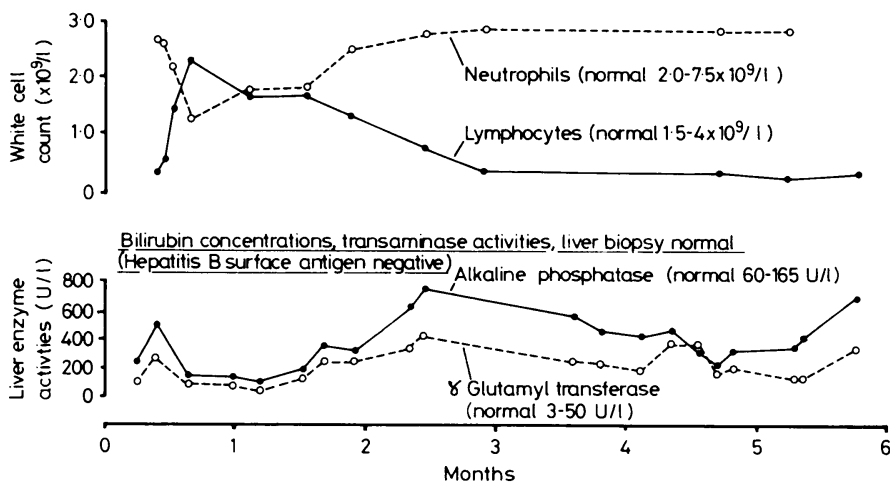

Summary of clinical findings showing daily temperature (measured at 1800), drug treatment, titre of antibodies to cytomegalovirus, serial white cell count, and liver enzyme activities.

the unusual infections seen in patients receiving cytotoxic treatment and by the occurrence of primary cerebral lymphoma in recipients of renal transplants.

Fever and diarrhoea commonly develop in homosexuals with the acquired immunodeficiency syndrome. ${ }^{135}$ Our patient was unusual in that no organisms accounting for his fever were isolated during four months of investigation. In this respect his impaired antibody responses to cytomegalovirus and toxoplasma indicate that the results of serological tests may be misleading when antibody production depends on the cooperation of $\mathrm{T}$ cells. A similar explanation may account for the absence of malarial antibodies. We did find evidence, however, of colonisation of the small bowel and pancreatic insufficiency (figure), which may have contributed to his diarrhoea. The distribution of cytomegalovirus in the liver without hepatic parencymal change represents an unusual form of infection by cytomegalovirus in adults.

Our patient's illness may have resulted from the combined immunosuppressive effects of cytomegalovirus, malaria or other infections, and, latterly, malnutrition. Serological tests may be inappropriate for diagnosis when antibody production depends on the cooperation of $T$ cells. Our study emphasises the importance of considering acquired immunodeficiency as a cause of fevers of undetermined origin, particularly in view of the reliance normally placed on serological tests.

We thank Dr G Watkinson, Dr G G Birnie, and Professor M R Bond for their help in the management of this patient, Dr J F Boyd for performing 
the immunofluorescence studies, and Dr V Biggs for her advice during the preparation of the manuscript.

${ }^{1}$ Anonymous. Acquired immunodeficiency syndrome [Editorial]. Lancet $1983 ; \mathrm{i}: 162-4$

${ }^{2}$ Levy JA, Ziegler JL. Acquired immunodeficiency syndrome is an opportunistic infection and Kaposi's sarcoma results from secondary immune stimulation. Lancet 1983 ;ii :78-81.

${ }^{3}$ Anonymous. Update on acquired immunodeficiency syndrome (AIDS)United States. $M M W R$ 1982;31:507-8.

4 Brunet JB, Bouret E, Leiboustel J, et al. Acquired immunodeficiency syndrome in France. Lancet $1983 ; \mathrm{i}: 700$.

${ }^{5}$ Mildvan D, Mathur U, Enlow RW, et al. Opportunistic infections and immune deficiency in homosexual men. Ann Intern Med 1982;96:700-4.

(Accepted 3 October 1983)

Medical Unit and Department of Pathology, Western Infirmary, Glasgow G11 6NT

C R SHIACH, BSC, MB, senior house officer

A D BURT, BSC, MB, registrar

C G ISLES, BSC, MRCP, senior registrar

S G BALL, PHD, MRCP, consultant physician

Correspondence to: Dr S G Ball, Medical Research Council Blood Pressure Unit, Western Infirmary.

\section{Risk of giving intravenous aminophylline to acutely ill patients receiving maintenance treatment with theophylline}

Drug monitoring has showr: that the efficacy ${ }^{1}$ of theophylline can be enhanced by maintaining the serum concentration at the upper end of the accepted therapeutic range $(10-20 \mathrm{mg} / \mathrm{l})$. Although the drug is safe when taken over long periods by patients in stable clinical states because its rate of clearance is constant, it may be toxic during acute illnesses, when its rate of clearance may suddenly fall. ${ }^{2}$ Giving an intravenous bolus of aminophylline as emergency treatment to acutely ill patients increases the danger. This was illustrated by a recent case in which the serum theophylline concentration on admission was $64 \mathrm{mg} / \mathrm{l}$ before a bolus of aminophylline was given. ${ }^{3} \mathrm{We}$ undertook the present study to assess the risk of giving intravenous aminophylline to acutely ill patients already receiving oral theophylline.

\section{Patients, methods, and results}

Patients thought by the admitting officer to require emergency treatment with intravenous aminophylline were questioned about their regular drug treatment, and 25 who were receiving oral theophylline were studied. Eleven were subsequently treated with a continuous infusion of aminophylline. We recorded details of drug dosage, dosing interval, and the exact time the last tablet was taken. A $5 \mathrm{ml}$ blood sample was taken, separated, and stored at $-20^{\circ} \mathrm{C}$ for later analysis by enzyme immunoassay (EMIT).

We collected 26 samples from the 25 patients (one patient was admitted twice), who comprised 13 men and 12 women with exacerbations of bronchitis or asthma whose mean (SD) age was 61.7 (17) years. Three patients were smokers; no ex-smoker had smoked within the past three years. The mean daily dose of theophylline was 571 (202) $\mathrm{mg}$ (range 354-992 mg), and the mean time between the last dose and the blood sample was $7 \cdot 7$ (range 1-21) hours.

The table shows the serum theophylline concentrations, which ranged from 2 to $31.2 \mathrm{mg} / \mathrm{l}$; they were below the therapeutic range in 10 samples and within the therapeutic range in 12 . Four patients already had potentially toxic concentrations: two (cases 22 and 15, with concentrations of $25 \mathrm{mg} / 1$ and $31.2 \mathrm{mg} / \mathrm{l})$ had been given $250 \mathrm{mg}$ aminophylline intravenously by their general practitioners one and four hours respectively before admission. A third patient so treated (case 9) had a serum concentration of $11.9 \mathrm{mg} / \mathrm{l}$ four hours after the bolus injection, having taken his usual oral dose $10 \frac{1}{2}$ hours before giving the blood sample.

\section{Comment}

Although only four ( $16 \%$ ) of these 25 patients presented with serum concentrations in the toxic range, a further nine $(36 \%)$ had concentra- tions of over $11 \mathrm{mg} / \mathrm{l}$; administration of $250 \mathrm{mg}$ aminophylline in these patients, which raises the serum concentration by about $9 \mathrm{mg} / 1,{ }^{4}$ would have taken the concentrations into the toxic range. In 12 of the 26 samples the theophylline concentration was already within the therapeutic range, which raises the question of whether aminophylline treatment was appropriate. Considerable benefit may be obtained by maintaining the theophylline concentration close to $20 \mathrm{mg} / 1,{ }^{1}$ but some workers suggest that beta adrenergic agonists may be more effective in acute asthma. ${ }^{5}$ For patients with initial concentrations of less than $10 \mathrm{mg} / \mathrm{l}$ an intravenous bolus followed by a maintenance infusion of aminophylline would clearly be beneficial, but monitoring of serum theophylline concentrations is necessary.

Details of daily doses of theophylline and serum concentrations after given times in 25 patients

\begin{tabular}{|c|c|c|c|}
\hline Case No & $\begin{array}{l}\text { Daily dose of } \\
\text { theophylline (mg) }\end{array}$ & $\begin{array}{l}\text { Time between dose } \\
\text { and blood sample } \\
\text { (hours) }\end{array}$ & $\begin{array}{l}\text { Serum theophylline } \\
\text { concentration }(\mathrm{mg} / \mathrm{l})\end{array}$ \\
\hline $\begin{array}{r}1 \\
2 \\
3 \\
4 \\
5 \\
6 \\
7 \\
8 \\
9 \\
10 \\
11 \\
12 \\
13 \\
14 \\
15 \\
16 \\
17 \\
18 \\
19 \\
20 \\
21 \\
22 \\
23 \\
24 \\
25\end{array}$ & $\begin{array}{l}708 \\
354 \\
708 \\
708 \\
354 \\
354 \\
708 \\
708 \\
708 \\
354 \\
708 \\
354 \\
531 \\
708 \\
708 \\
992 \\
354 \\
531 \\
354 \\
354 \\
531 \\
354 \\
577 \\
354 \\
885\end{array}$ & 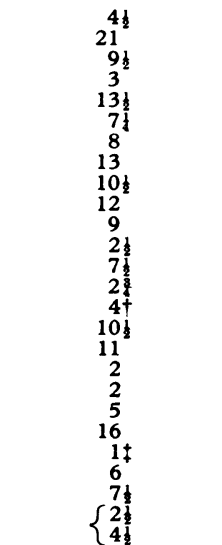 & $\begin{array}{r}11.8 \\
11.2 \\
2.0 \\
20.5 \\
10.8 \\
10.5 \\
6.2 \\
20.4 \\
11.9 \\
3.5 \\
14.1 \\
11 \cdot 2 \\
2.0 \\
15.3 \\
31.2 \\
5.9 \\
2.0 \\
8.6 \\
18.1 \\
5.6 \\
3.6 \\
25.0 \\
11.1 \\
9.2 \\
17.0 \\
11.0\end{array}$ \\
\hline
\end{tabular}

- 4 hours, $+1 \frac{1}{2}$ hours, $\ddagger 1$ hour after aminophylline $250 \mathrm{mg}$ given intravenously.

This study confirms that almost half the patients who regularly take theophylline are at risk from theophylline poisoning when given an intravenous bolus of aminophylline. When such patients are admitted to hospital acutely ill it would be safer to start a maintenance infusion equivalent to the oral dose and await the result of assay of serum theophylline concentrations before giving a bolus of the drug. Giving aminophylline to such patients may be hazardous when monitoring facilities are not available. Many patients do not require a bolus, and for others an aminophylline infusion is inappropriate.

We thank Drs G J Addis and W McMurray, who gave helpful advice with the text, and Miss M Montgomerie for typing the manuscript. The EMIT assay kits were provided by Napp Laboratories.

1 Vozeh S, Kevitz G, Perruchoud A, et al. Theophylline serum concentration and therapeutic effect in severe acute bronchial obstruction: the optimal use of intravenously administered aminophylline. Am Rev Respir Dis 1982;125:181-4.

2 Powell JR, Vozeh S, Hopewell P, Costello J, Scheiner LB, Reigelman S. Theophylline disposition in acutely ill hospitalised patients. Am Rev Respir Dis 1978;118:229-37.

${ }^{3}$ Thomson PJ, Hay JG. Dangers of compound drugs and intravenous aminophylline. Lancet 1982 ;ii:1228.

4 Nicholson DP, Chick TW. A re-evaluation of parenteral aminophylline. Am Rev Respir Dis 1973;108:241-7.

${ }^{5}$ Rossing TH, Fanta CH, Goldstein DH, Snapper JR, McFadden ER. Emergency therapy of asthma: comparison of the acute effects of parenteral and inhaled sympathomimetics and infused aminophylline. Am Rev Respir Dis 1980;122:365-71.

(Accepted 10 November 1983)

Wythenshawe Hospital, Manchester M23 9LT

M FELICITY STEWART, BSC, MB, registrar in chemical pathology JOYCE BARCLAY, MB, MRCP, senior registrar in cardiothoracic medicine RAY WARBURTON, MSC, PHD, senior biochemist

Correspondence to: $\mathrm{Dr} M$ Felicity Stewart, Department of Chemical Pathology, Hope Hospital, Salford M6 8HD. 